\title{
ESTIMATION OF THE MODERN STATE OF PROVISION OF AGRICULTURAL ENTERPRISES IN MYKOLAIV REGION BY MATERIAL AND TECHNICAL RESOURCES
}

\author{
Natalya POTRYVAIEVA', Inha AHEIENKO² \\ Mykolaiv National Agrarian University, Ukraine
}

\begin{abstract}
The research considers the issue of the provision of agrarian enterprises in Ukraine by material and technical resources and effective use of them. The scientific novelty of the results obtained is in the research of theoretical positions, substantiation of applied approaches concerning the organization of material and technical provision of enterprises of the agrarian sector, in particular, Mykolaiv region, taking into account the proposals of the second market of agricultural machinery, units, and aggregates. Methodology. The purpose of the article is the research and estimation of the current state of the provision of agrarian enterprises by material and technical resources. The object of scientific research is the process of provision of material and technical resources for enterprises of the agrarian sector in Mykolaiv region. The level of material and technical resources at agricultural enterprises in Mykolaiv region is analysed. Relative improvement of the situation with technical equipment and energy supply of agriculture in the Mykolaiv region since 2014 is defined; however, the dynamics are not active sufficiently and do not exceed five percent. The ratio between the amount of machinery purchased and disposed of by depreciation is disproportionate, the equipment provided by the unit of area, and the load on the machines available in the farms do not meet the requirements. The dynamics of capital and direct foreign investments in agriculture of Mykolaiv region, which during the research period increased, is investigated. It is proved that despite the rather successful development of capital investments by large-scale agricultural producers in the region, financial investments in modernization, repair, and acquisition of the new technology by small business entities are not sufficiently active. The authors substantiate that the tasks of technical re-equipment for commodity producers of the Mykolaiv region remain one of the most important, the search for prospective ways of its renewal is urgent. In particular, the authors proposed to intensify the formation of the secondary market of restored agricultural machinery based on the experience of foreign countries. Progressive improvement of material and technical resources is seen in the development of a network of local leasing funds and funds of preferential lending to agricultural commodity producers; expansion of cooperative forms of acquisition and exploitation of high-tech; the growth of dealer centres that provide rural commodity producers with equipment on leasing terms. In the conclusions, it is proved that the reduction of the number of the main types of equipment at agricultural enterprises in Mykolaiv region led to the fact that most of the technics are used longer the normative lifetime, on-load for each type of equipment is constantly increasing due to its scarcity. Improvement of the efficiency and growth of agricultural production and the level of its intensification needs updating of the material and technical base of agricultural enterprises, which requires significant investments. Taking into account the implementation of the region targeted programs, the role of public authorities is to develop measures aimed at a comprehensive solution to problems related not only to the implementation of technical, investment, and innovation policies but also to the coordinated co-operation between the industrial, commercial, and financial strategy.
\end{abstract}

Key words: agricultural enterprises, material and technical resources, fixed assets of production, energy supply, capital and direct investments.

JEL Classification: Q19, O13, L23, Q43, P45

\footnotetext{
Corresponding author:

${ }^{1}$ Department of Accounting and Taxation, Mykolaiv National Agrarian University.

E-mail: potrivaeva@mnau.edu.ua

${ }^{2}$ Department of Accounting and Taxation, Mykolaiv National Agrarian University.

E-mail: ingapelipkanich@gmail.com
} 


\section{Introduction}

The most important factor of production, especially in the conditions of scientific and technical progress, when the number of labour resources employed in production is decreasing, there are material and technical resources, among which the leading role is played by the fixed assets of production at the enterprises of the agrarian industry. According to statistics, the average annual value of fixed assets in the last 15 years has decreased more than twice, and in the last 5 years - by one third (Main department of statistics in Mykolaiv region: The Official site). Moreover, the coefficient of their elimination is constantly ahead of the update factor. That is, the majority of domestic agricultural enterprises are characterized by rather a slow pace of renovation of material and technical resources of production at a relatively high level of discharges, depending on the degree of their technical feasibility.

The situation that has developed over recent years with the reproduction of material and technical resources of agrarian enterprises is largely determined by the accelerated growth of prices for industrial products in comparison with agricultural products, which resulted in the formation and preservation of price disparity. Such a state cannot contribute to the effective development of agricultural production and needs coordinated structural changes in the national economy in general. Therefore, the search for ways of providing enterprises and efficient use of their material and technical resources is a very topical issue of the present day and it makes it necessary to assess the current state of provision of agricultural enterprises with material and technical resources. So, the search for ways of the provision of enterprises and effective use of their material and technical resources is a very topical issue and causes the necessity to assess the current state of provision of agricultural enterprises with material and technical resources.

The scientific novelty of the results obtained is in the research of theoretical positions, substantiation of applied approaches concerning the organization of material and technical provision of enterprises of the agrarian sector, in particular, Mykolaiv region, taking into account the proposals of the second market of agricultural machinery, units, and aggregates.

\section{The aim, task, and object of the study}

The study is aimed at a complete and reliable assessment of the current state of provision of agricultural enterprises in Mykolaiv region by material and technical resources. To achieve the research goal, the following tasks are set:

- to summarize the results of theoretical studies on the essence and content of material and technical provision in agriculture;

- to study methodical approaches to the estimation of material and technical means of agricultural enterprises;
- to assess the level of provision and use of material and technical means of agricultural producers in Mykolaiv region;

- to substantiate the proposals on the improvement of prov ision by material and technical means of agrarian enterprises in the region.

The object of the study is the process of provision of agricultural enterprises in Mykolaiv region by material and technical means. The subject of the study is a set of theoretical, methodological, and practical aspects of the formation of the material and technical provision at agricultural enterprises.

\section{Methods of the study}

The theoretical and methodological basis of the study provided is the works of domestic and foreign scientists on the issues of material and technical provision. The research uses the following methods: bibliographic (in the study of recent scientific publications and practical achievements in the subject; in developing specific research objectives) and system analysis, graphical (in the construction of graphs, diagrams), and statistical (in determining the factors of influence on the resulting indicator).

\section{The state of studying the problem}

The issues concerning the state of supply of agricultural enterprises with material and technical resources were investigated by Y. Hvozdiev, I. Herasymenko, T. Didorenko, H. Maiduda, M. Mohylova, O. Nuzhna, I. Svynous, O. Cherkasov, Y. Shahovalova and other scientists.

Such scientists as Y. Hvozdiev and I. Herasymenko (Hvozdiev, 2016), M. Mohylova (Mohylova, 2016), O. Nuzhna (Nuzhna, 2015) highlight features and components of the system analysis of material and technical resources of commodity producers in the industry and methodical approaches to assessing the use and status of fixed assets of agricultural enterprises. In turn, H. Maiduda (Maiduda, 2015), O. Cherkasov (Cherkasov, 2015, 2016) and Y. Shahovalova (Shahovalova, 2015) aimed their studies at exploring the state and structure of financial resources for the reproduction of material and technical resources in the industry. T. Didorenko (Didorenko, 2016) was engaged in the classification of material and technical resources at agricultural enterprises according to their function and role in the process of production.

I. Svynous, N. Khomiak, O. Rudych (Svynous, 2016) analyse the role and place of the state in the process of reproduction of fixed assets of agricultural enterprises in their studies. The scientists believe the state support measures should stimulate expanded reproduction and increase of the production of agricultural products mainly at their own expense. In addition, only in the combination 
of theoretical and methodological provisions and methodical tools from the point of view of the system approach may connect reproductive flows and provide technical base updates and their economic growth.

\section{Presentation of the major research material}

The basis for the stabilization and expansion of agricultural production is the material and technical resources, the most important part of which are agricultural machinery and equipment. We analysed the level of material and technical resources at agricultural enterprises in Mykolaiv region. The main indicators of material and technical resources based on statistical information are presented in Table 1.

As a result of the study of the average annual value of non-current and current assets of the agrarian enterprises in Mykolaiv region, it is found that the lowest result was in 2013, namely, by almost 5\% less than in 2012 and by $43.4 \%$ less than the indicator of the reported year. Similarly, in 2013, the energy capacities and the main agricultural machinery were fixed less than in 2012 and in 2014-2015, fewer indicators were observed only in 2011.

The presence of livestock and poultry in agricultural enterprises of Mykolaiv region had been increasing by 2013 but from 2014 the value of the indicator is steadily decreasing and the smallest result was fixed in 2015 (Main department of statistics in Mykolaiv region: The Official site).
Thus, the situation with technical equipment and energy supply of agriculture in Mykolaiv region has improved since 2014, but the dynamics are not sufficiently active and do not exceed 5\%.

The most active part of the material and technical base of agricultural enterprises is energy resources, which include the power of mechanical engines (tractors, combines, cars, etc.), electric motors, electrical installations and working cattle. Among the energy resources of agrarian enterprises, mechanical motors prevail, and the share of working cattle is less than $0.5 \%$. As a part of energy resources, the main place is occupied by tractor and automobile engines, which account for approximately $2 / 3$ of all capacities.

Analysing the resource potential of agriculture in Mykolaiv region, we made the main focus on agricultural enterprises; their provision with agricultural machinery is given in Table 2 .

The average power of a single tractor engine in 2015 was $93.4 \mathrm{~kW}$, which is not enough to use resourcesaving and high-performance technologies, where tractors with an average engine power of $100 \mathrm{~kW}$ are required. Nowadays, enterprises of Mykolaiv region need to have 13 tractors per 1000 hectares of arable land, and 10.5 units of grain harvesters, 12.6 units of beet-harvesting machines, 17 units of potato harvesters (since 2013 the region has not had any of such combines at all) per 1000 hectares of crops are necessary; at the same time in 2015, 18.9 thousand hectares of potatoes were grown (Shabala). The acquisition of the main

Table 1

The state of material and technical resources of agricultural enterprises of Mykolaiv region

\begin{tabular}{|l|c|c|c|c|c|c|}
\hline \multicolumn{1}{|c|}{ Indicators } & \multicolumn{3}{c|}{ Year } & $\begin{array}{c}\text { Deviation in 2015 } \\
\text { in \% until 2011 }\end{array}$ \\
\cline { 2 - 8 } & 2011 & 2012 & 2013 & 2014 & 2015 & 127,7 \\
\hline $\begin{array}{l}\text { Average annual value of non-current and current } \\
\text { assets, million UAH }\end{array}$ & 2543,6 & 2377,2 & 2264,0 & 2565,6 & 3247,0 & 112,4 \\
\hline Availability of power capacities, ths. KW & 1306,2 & 1421,6 & 1406,7 & 1462,1 & 1468,1 & 118,4 \\
\hline Energy capacities per 100 hectares of sown area, kW & 125 & 146 & 139 & 146 & 148 & 103,7 \\
\hline Availability of basic agricultural machinery, pcs. & 9212,2 & 9572,6 & 9371,7 & 9479,1 & 9551,1 & 84,7 \\
\hline Livestock and poultry, thousand conventional heads & 177 & 174 & 185 & 155 & 150 & \\
\hline
\end{tabular}

Source: compiled by the author based on the data of the Main Department of Statistics in Mykolaiv region (Main department of statistics in Mykolaiv region: The Official site)

Table 2

Availability of main types of equipment at agricultural enterprises of the Mykolaiv region

\begin{tabular}{|c|c|c|c|c|c|c|}
\hline \multirow{2}{*}{ Types of agricultural equipment } & \multicolumn{5}{|c|}{ Year } & \multirow{2}{*}{$\begin{array}{l}\text { Deviation in } 2015 \\
\text { in\% until } 2011\end{array}$} \\
\hline & 2011 & 2012 & 2013 & 2014 & 2015 & \\
\hline Tractors - total, pcs. & 6339 & 6537 & 6481 & 6538 & 6573 & 103,7 \\
\hline Tractors per 1000 hectares of arable land, pcs. & 6 & 7 & 7 & 7 & 7 & 116,7 \\
\hline Power of tractor engines, ths. KW & 534,0 & 572,9 & 561,6 & 589,0 & 614,1 & 115,0 \\
\hline Grain harvesters, pcs. & 1338 & 1410 & 1295 & 1258 & 1292 & 96,6 \\
\hline Corn harvesters, pc. & 87 & 81 & 70 & 88 & 78 & 89,7 \\
\hline Potato harvesters, pcs. & 3 & 3 & - & - & - & - \\
\hline Beet-harvesting machines, pc. & 62 & 56 & 47 & 43 & 43 & 69,4 \\
\hline Milking establishments and devices, pcs. & 167 & 148 & 142 & 178 & 175 & 104,8 \\
\hline
\end{tabular}

Source: compiled by the author based on the data of the Main Department of Statistics in Mykolaiv region (Main department of statistics in Mykolaiv region: The Official site) 
types of equipment in the agrarian sector of Mykolaiv region is shown in Table. 3.

Analysis of the acquisition of the main types of equipment to the agricultural enterprises of Mykolaiv region in 2015 (Table 3) proved that only a number of tractors, drills, spreaders offertilizers and grain harvesters had increased. For other types of technical means, both in crop production and in animal husbandry, there was a reduction. Consequently, the situation regarding the availability of tractors, combines, and other types of equipment on agro-enterprises of Mykolaiv region is quite critical, which is due to a violation of the ratio between the number of purchased and disposed equipment. In turn, the reduction of the number of basic types of equipment has led to a deterioration of indicators of equipment availability per area unit and increase in a load of existing machines at the enterprises. The area of grain crops grown by agricultural enterprises of the region in 2015 was about 950 thousand hectares. At the beginning of the reporting period, 1292 grain harvesters were involved in the industry. The load on a single combine harvester was 735 hectares instead of standard 130 hectares. Because of this, the work took a longer period of time, which led to a significant loss of crops and lower quality of products. In addition, most of the technology will require qualitative upgrades and modernization (Mykolaiv Regional State Administration: The Official site).

We consider it appropriate to analyse the dynamics of capital and direct investments in agriculture in the region in 2010-2015 (Fig. 1).

As it can be seen, the level of financial investments in the region's agriculture since 2012 has gained a positive upward trend. Thus, capital investments in 2015 increased

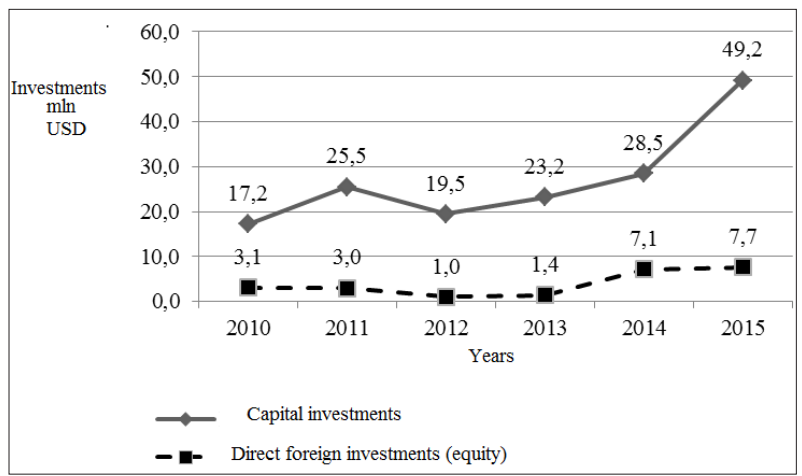

Fig. 1. Dynamics of capital and direct investments in agriculture of Mykolaiv region

Source: compiled by the author based on the data of the Main Department of Statistics in Mykolaiv region (Main department of statistics in Mykolaiv region: The Official site)

by 2.5 times compared to 2012 (the lowest figure since 2011 ), and by $72.7 \%$ compared to 2014 . At the same time, the direct foreign investments in reporting period increased by 7,6 times compared to 2012 and by $8 \%$ as to the previous year (Main department of statistics in Mykolaiv region: The Official site).

It was in the years of 2013-2015 that more than 15 major investment projects were implemented, including the largest in the field of plant growing: the construction of the transshipment terminal for 70 thousand tons in the city of Nova Odesa by the limited liability company, the joint venture Nibulon; the reconstruction of the granary with the total capacity of 30 thousand tons of the limited liability company "Mykolaivske Zernoskhovyshche". "Blagodatnensky Ptahoprom" Joint Stock Company in Arbuzynskyi district has started construction of a grain

Table 3

Acquisition (disposal) of the main types of equipment to the agricultural enterprises of Mykolaiv region in 2015

\begin{tabular}{|c|c|c|c|c|c|}
\hline \multirow[b]{2}{*}{ Types of equipment } & \multicolumn{2}{|c|}{ Availability } & \multirow[b]{2}{*}{ Types of equipment } & \multicolumn{2}{|c|}{ Availability } \\
\hline & $\begin{array}{c}\text { On } \\
01 / 01 / 2015 \text {, pcs. }\end{array}$ & $\begin{array}{l}\% \text { to availability } \\
\text { at the beginning } \\
\text { of the year }\end{array}$ & & $\begin{array}{c}\text { On } \\
01 / 01 / 2015 \text {, pcs. }\end{array}$ & $\begin{array}{c}\% \text { to availability } \\
\text { at the beginning } \\
\text { of the year }\end{array}$ \\
\hline Tractors & 6573 & 101,3 & Harvesting combines & 174 & 94,6 \\
\hline Drills & 4374 & 103,7 & $\begin{array}{l}\text { Potato harvesters and potato- } \\
\text { diggers }\end{array}$ & 18 & 90,0 \\
\hline Potato planters & 29 & 96,7 & $\begin{array}{l}\text { Combines and beet- } \\
\text { harvesting machines } \\
\text { (without beet-cutting } \\
\text { machines) }\end{array}$ & 43 & 93,5 \\
\hline $\begin{array}{l}\text { Spreaders of manure } \\
\text { and fertilizers }\end{array}$ & 857 & 106,2 & $\begin{array}{l}\text { Machines and combines for } \\
\text { harvesting vegetables and } \\
\text { melons }\end{array}$ & 36 & 87,8 \\
\hline Sprinklers & 191 & 96,0 & $\begin{array}{l}\text { Milking installations and } \\
\text { apparatus }\end{array}$ & 175 & 96,2 \\
\hline Grain harvesters & 1292 & 100,8 & Incubators & 57 & 86,4 \\
\hline Con harvesters & 78 & 94,0 & $\begin{array}{l}\text { Conveyors for manure } \\
\text { removal }\end{array}$ & 384 & 99,0 \\
\hline
\end{tabular}

Source: compiled by the author based on the data of the Main Department of Statistics in Mykolaiv region (Main department of statistics in Mykolaiv region: The Official site) 
storage facility with a capacity of 100 thousand tons, 50 thousand tons of which have already been put into operation for the first time and a reconstruction of a feed mill with a capacity of 30 thousand tons of feed per year has been carried out. The joint-stock company with limited liability "Promin" in Arbuzynskyi district built a grain storage facility with a capacity of 22 thousand tons and also built 4 greenhouses for the cultivation of early vegetables and seedlings of vegetable crops on the area of 4.5 hectares; 3 vegetable stores with capacity of 14 thousand tons of simultaneous storage were put into operation (Mykolaiv Regional State Administration: the Official site).

In the field of livestock breeding, 16 objects were put into operation, 9 units were constructed, and 7 units were reconstructed, their total capacity is 1140 for cattle and 6,100 for pigs. The largest of these investment projects is a dairy complex for 2,000 cows in the joint-stock company with limited liability "Promin" in Arbuzynskyi district, where 1300 milk cows are housed with the use of the latest technology and they give 35 tons of high-quality milk every day, and the productivity of the cows was the largest in Ukraine and made about 10 tons of milk per cow. Similar works in dairy cattle breeding are carried out at a number of other farms, such as the Limited Liability Company "Kolos-2011" in Ochakivsky district and a private joint-stock company "Ukraine" in Domanivsky district. In the field of swine breeding, the modern pig farms were put into operation at the private enterprise "Tekhmet-Yuh" in Vitovskyi district and at the farm "Agro-1" in Novobuzkyi district (Mykolaiv Regional State Administration: The Official site).

Despite the rather successful development of capital investments by large commodity producers in the Mykolaiv region, financial injecting into modernization, repair, and acquisition of new technology by small business entities is not quite active. Thus, the task of technical re-equipment for commodity producers in the area remains one of the most important.

In such circumstances, the budget funds allocated for the renovation of the material and technical base of agriculture are gradually decreasing; therefore, it is necessary to search for other ways of its renewal. In particular, it is necessary to intensify the formation of the secondary market of restored agricultural machinery. Thus, the system of second-hand equipment sales has been rapidly developing in the economically developed countries. This tendency can be traced in the USA, Canada, Australia, and the six most agrarian countries in Western Europe. The outdated low-performance equipment is gradually withdrawn from economic circulation and enters the secondary market in these countries. Thus, for example, in the USA the share of used tractors with engine power from 40 to $100 \mathrm{hp}$ sales exceeds $87 \%$, and for tractors with engine power more than $200 \mathrm{hp}$ it accounts a little more than $2 \%$ (Petrov).

In European countries, the discharged tractors are being sold off on the secondary market; they are three times more than new ones. The service life of tractors is 4-5 years, for grain harvesters it makes 3-4 years. The sale of equipment takes place through a dealer system after a quality repair and maintenance, while its cost is $30 \%$ less than the original. The incentive for all participants in the secondary market is profit since capital repairs cost 2-3 times cheaper than buying a new one. It should be noted that domestic enterprises have accumulated at least a positive experience in the recovery of machines, assemblies, and units (Pylypenko).

We consider Mykolaiv region needs to pay attention to: the development of a network of local leasing funds and funds for preferential lending to agricultural producers; the expansion of cooperative forms of acquisition and exploitation of expensive machinery; the growth of dealer centres that provide rural commodity producers with equipment on lease terms.

\section{Conclusions and perspectives of further research}

The results of the study prove that the reduction in a number of the main types of equipment at agricultural enterprises in Mykolaiv region has led to the deterioration of the indicators of equipment availability per area unit and to increase in the load on machinery available on farms. Currently, the tractor and combine park renewal ratio does not exceed 5\%, while its rate should be $10-12 \%$. In such conditions, a large part of the technology is used longer than the normative term of operation, the load on each type of equipment is constantly increasing due to its lack.

In order to increase the efficiency and increase the volume of agricultural production, and the level of its intensification, it is necessary to further upgrade the material and technical base of agricultural enterprises, which requires tremendous investments. Taking into account the implementation of the region targeted programs, the technical equipment of medium and small agricultural producers in modern economic conditions does not meet normative recommendations.

The role of public authorities is to develop measures aimed at a comprehensive solution to problems related not only to the implementation of technical, investment, and innovation policies, but also to the coordinated co-operation between the industrial, commercial, and financial strategy. 


\section{References:}

Hvozdiev, Yu. V. (2016). Methodical approaches to assessment of fixed assets at agricultural enterprises. Agroworld, Vol.22, p. 27-31.

Didorenko, T.V. (2016). The essence and classification of material and technical resources at agricultural enterprises according to their purpose and role in the process of production. Ukrainian Journal of Applied Economics, Vol. 1, issue 1, p. 92-99.

Maiduda, H. S. (2015). Analysis and optimization of the structure of financial resources for the reproduction of fixed assets of agricultural enterprises. Accounting and finances, Vol.4, p. 105-111.

Mohylova, M. M. (2016). Improvement of basic agricultural fixed assets valuation in diagnostics of investment attractiveness and creditworthiness of agrarian enterprises. Investments: practices and experience, Vol.5, p. 22-27.

Mohylova, M. M. (2016). Transformation of the institutional environment for reproduction of fixed assets of agricultural enterprises in Ukraine. Herald of KhNAU. Series: Economic sciences, Vol.1 p.231-240.

Nuzhna, O. A. (2015). Fixed assets in Ukrainian agriculture: security and reproduction problems. Economic sciences. Series: Accounting and finances, issue 12(1), p. 215-223.

Main department of statistics in Mykolaiv region: the Official site. Electronic resource. Retrieved from: http://www.mk.ukrstat.gov.ua/

Mykolaiv Regional State Administration: the Official site. Electronic resource. Retrieved from: http://www.mk.gov.ua/ua/myko/agry/

Petrov, V. M. Pricing in the secondary market of agricultural machinery. Electronic resource. Retrieved from: http://dspace.knau.kharkov.ua/

Pylypenko, Ye. Tractors for sale: how the market of agricultural machinery intermediaries works. Electronic resource. Retrieved from: http://agravery.com/uk/posts/show/traktori-na-prodaz-ak-pracue-rinok-poserednikivsilgosptehniki

Svynous, I. V. (2016). The role and place of the state in the process of reproduction of fixed assets of agricultural enterprises. Innovational economics, Vol. № 3-4, p. 39-43.

Cherkasov, O. O. (2015). Features of use and reproduction of fixed assets in agriculture. State and regions. Series: Economics and entrepreneurship, Vol. 5, p. 96-101.

Cherkasov, O. O. (2016). System analysis of reproduction of fixed assets in agriculture. Scientific herald of Kherson State University. Series: Economic sciences, issue 16(3), p. 59-62.

Cherkasov, O. O. (2016) Financial support for reproduction of fixed assets in agriculture. Herald of Odessa National University. Series: Economics, Vol. 21, issue. 2, p. 110-114.

Shabala, M. O. Determination of the need for tractors. Electronic resource. Retrieved from: http://nauka.tsatu.edu.ua/e-journals-tdatu/pdf2t3/12smoedr.pdf

Shakhovalova, Ye. O. (2015). Strategy of financial support of reproduction of fixed assets in agriculture. Scientific journal of NPU named by M. P. Drahomanov, Series 18: Economics and law, issue 30, p. 50-56.

\section{Наталя ПОТРЫВАЕВА, Инга АГЕЕНКО}

\section{ОЦЕНКА СОВРЕМЕННОГО СОСТОЯНИЯ ОБЕСПЕЧЕННОСТИ СЕЛЬСКОХОЗЯЙСТВЕННЫХ} ПРЕДПРИЯТИЙ НИКОЛАЕВСКОЙ ОБЛАСТИ МАТЕРИАЛЬНО-ТЕХНИЧЕСКИМИ РЕСУРСАМИ

Аннотация. В исследовании рассмотрен вопрос обеспечения предприятий аграрного сектора экономики Украины материально-техническими средствами и их эффективного использования. Научная новизна полученных результатов заключается в исследовании теоретических положений и обосновании прикладных подходов к организации материально-технического обеспечения предприятий аграрной сферы, в частности Николаевской области с учетом предложений вторичного рынка сельскохозяйственной техники, узлов и агрегатов. Методология. Целью статьи было исследование и оценка современного состояния обеспеченности сельскохозяйственных предприятий материально-техническими ресурсами. Объектом научной разведки был выбран процесс обеспечения материально-техническими средствами аграрного сектора экономики Николаевской области. Проанализирован уровень материально-технических ресурсов на сельскохозяйственных предприятиях Николаевской области. Установлено относительное улучшение ситуации с технической оснащенностью и энергообеспеченностью сельского хозяйства Николаевского региона с 2014 г., однако динамика не является достаточно активной и не превышает пяти процентов. Соотношение между количеством приобретенной и выбывшей по сносу техники непропорциональное, обеспеченность техникой на единицу площади и нагрузка на имеющиеся в хозяйствах машины не отвечают требованиям. Исследована динамика капитальных и прямых иностранных инвестиций в сельское хозяйство Николаевской области, которые за период исследования увеличились. Доказано, что вопреки достаточно успешному освоению капитальных инвестиций крупнотоварными агропроизводителями 
региона, финансовые вливания в модернизацию, ремонт и приобретение новой техники субъектами малого предпринимательства происходит недостаточно активно. Авторами обосновано то, что задание технического перевооружения для товаропроизводителей Николаевской области остается одним из наиважнейших, актуальным является поиск перспективных способов его обновления. В частности, авторами предложено активизировать формирование вторичного рынка восстановленной сельскохозяйственной техники по опыту зарубежных стран. Прогрессивным путем улучшения материально-технического обеспечения усматривается развитие сети местных лизинговых фондов и фондов льготного кредитования сельскохозяйственных товаропроизводителей; расширение кооперативных форм приобретения и эксплуатации дорогостоящей техники, рост дилерских центров, которые обеспечивают сельских товаропроизводителей техникой на условиях лизинга. В выводах было доказано, что сокращение количества основных видов техники в сельскохозяйственных предприятиях Николаевской области привело к тому, что большая часть техники используется за пределами нормативного срока эксплуатации, постоянно растет нагрузка на каждый вид техники вследствие ее нехватки. Повышение эффективности и рост объемов производства сельскохозяйственной продукции, уровня его интенсификации требует обновления материально-технической базы сельскохозяйственных предприятий, которое требует значительных вложений средств. Ввиду реализации областных целевых программ роль органов государственной власти заключается в разработке мероприятий, направленных на комплексное решение задач, связанных не только с реализацией технической, инвестиционной и инновационной политики, но и скоординированных между собой промышленной, торговой и финансовой стратегий. 